\title{
GAMBARAN KEDUKAAN PADA PEREMPUAN DEWASA MADYA YANG PERNAH MENGALAMI KEGAGALAN PROGRAM IN VITRO FERTILIZATION
}

\author{
Giovanni Patricia ${ }^{1}$, Riana Sahrani ${ }^{2}$ dan Agustina $^{3}$ \\ ${ }^{1}$ Fakultas Psikologi, Universitas Tarumanagara Jakarta \\ Email: giovanni_patricia@yahoo.com \\ ${ }^{2}$ Fakultas Psikologi, Universitas Tarumanagara Jakarta \\ Email: rianas@fpsi.untar.ac.id \\ ${ }^{3}$ Fakultas Psikologi, Universitas Tarumanagara Jakarta \\ Email: agustina@fpsi.untar.ac.id
}

\begin{abstract}
ABSTRAK
Kedukaan merupakan suatu respon yang dialami oleh manusia ketika mereka kehilangan orang yang dikasihi. Berdasarkan penelitian sebelumnya, ketika seorang perempuan mengalami kegagalan pada program IVF-nya, mereka akan mengalami kedukaan yang cukup dalam. Menurut Kübler-Ross (2009), respon kedukaan memiliki lima tahapan di antaranya denial, anger, bargaining, depression dan acceptance. Tujuan dari penelitian ini yaitu untuk mengetahui gambaran kedukaan perempuan yang mengalami kegagalan program IVF. Penelitian ini merupakan penelitian kualitatif dengan teknik pengambilan sampling yaitu purpose criterion sampling, yang melibatkan empat subyek yang pernah mengalami kegagalan program IVF. Hasil dari penelitian yang dilakukan menunjukkan bahwa tiga dari empat subyek melewati semua tahapan kedukaan yang telah dikemukakan oleh Kübler-Ross. Selain itu, dua dari empat subyek memiliki faktor hubungan dengan calon bayi dalam rahim mereka sehingga mempengaruhi proses kedukaan mereka. Tiga dari empat subyek memiliki faktor proses kematian pada calon bayi mereka. Semua subyek mendapat dukungan sosial dari orang-orang terdekat mereka sehingga mereka dapat melewati proses kedukaan mereka. Selain itu berdasarkan hasil penelitian, faktor kepribadian, usia dan jenis kelamin tidak mempengaruhi kedukaan perempuan yang mengalami kegagalan program IVF.
\end{abstract}

Kata Kunci: Kedukaan, In Vitro Fertilization, Perempuan, Dewasa Madya

\section{PENDAHULUAN}

Menurut Erikson (dikutip dalam Papalia \& Feldman, 2012) pada usia dewasa madya umumnya, individu sedang menjalani tugas perkembangan generativity vs stagnation. Dalam tugas perkembangan ini, individu umumnya sudah menikah dan sudah mulai memperisapkan anak-anaknya untuk melanjutkan generasi keluarga mereka. Akan tetapi, ada juga pasangan suami istri yang sudah memasukki usia dewasa madya, namun beum dikaruniai anak. Pada umumnya, penyebab pasangan suami istri sulit untuk memiliki anak adalah karena masalah infertilitas.

In Vitro Fertilization (IVF) atau proses bayi tabung merupakan suatu proses di mana sel telur dibuahi oleh sperma di luar tubuh (Crawford \& Unger, 2000). Pada umumnya, alasan pasangan suami istri mengikuti program IVF adalah karena mereka ingin memiliki anak dan mereka sudah melakukan segala upaya untuk dapat hamil namun tetap tidak berhasil (Lusianti \& Wirawan, 2009). Akan tetapi, proses ini memiliki risiko yang cukup besar. Obat kesuburan dan sejumlah operasi yang dijalani dapat menyebabkan efek samping dan komplikasi yang tidak diinginkan dan cenderung berbahaya. Selain itu, biaya yang dikeluarkan untuk sekali percobaan tidaklah murah, yaitu berkisar 150 juta termasuk program IVF, screening yang dilakukan terhadap embrio yang dihasilkan dan pembekuan embrio yang telah dihasilkan dari 
proses penyuntikan sel sperma dan sel telur (Komunikasi Pribadi, 2017). Kemudian, hal yang disayangkan adalah teknik ini memiliki tingkat keberhasilan yang rendah, yaitu hanya sekitar 10 persen pada tiap percobaan (Crawford \& Unger, 2000). Oleh karena itu pada umumnya, ketika seorang perempuan mengalami kegagalan program IVF-nya, ia akan mengalami kedukaan (Lusianti \& Wirawan, 2009).

Menurut Stroebe (1987), kedukaan (grief) merupakan respon emosional serta reaksi psikologis dan somatis terhadap suatu peristiwa kehilangan. Menurut Kübler-Ross (2009), ada lima tahap yang dimiliki oleh diri individu ketika sedang mengalami kedukaan di antaranya denial, anger, bargaining, depression, dan acceptance. Menurut Aiken (dikutip dalam Cahyasari \& Sedjo, 2008), kelima tahap kedukaan ini dipengaruhi oleh beberapa faktor diantaranya hubungan dengan orang yang mengalami kematian tersebut, kepribadian, usia, jenis kelamin dari individu yang ditinggalkan, proses kematian yang dialami oleh orang yang mengalami kematian tersebut dan dukungan sosial dari orang-orang terdekat. Jadi berdasarkan teori dari Aiken (dikutip dalam Cahyasari \& Sedjo, 2008), tentang faktor yang mempengaruhi proses dari setiap tahap kedukaan yang telah dikemukakan oleh Kübler-Ross (2009), dapat dikatakan bahwa kedukaan setiap perempuan yang pernah mengalami kegagalan program IVF bisa sangat bervariasi, baik dari segi cara hingga lama individu tersebut berduka atas kegagalan program IVF-nya. Tujuan dari penelitian ini untuk mengetahui gambaran kedukaan perempuan yang mengalami kegagalan dalam program IVF. Selain itu penelitiayang pernah menjan ini juga bertujuan untuk mengetahui lamanya mereka melewati masa kedukaannya dan apa yang dilakukan oleh perempuan dewasa madya ketika sedang mengalami masa kedukaan tersebut setelah mengalami kegagalan dalam menjalani program IVF.

\section{METODE PENELITIAN}

\section{Subyek penelitian}

Kriteria subyek yang diwawancara dalam penelitian ini adalah perempuan berusia 40 hingga 45 tahun, yang pernah untuk menjalani program IVF, dan mengalami kegagalan saat program IVF tersebut berlangsung serta hingga saat ini belum memiliki keturunan. Peneliti membuat kriteria subyek seperti ini untuk menunjang penelitian ini.

\section{Instrumen penelitian}

Penelitian ini menggunakan metode penelitian kualitatif dengan menggunakan metode wawancara in-depth interview. Dalam penelitian ini, instrumen yang digunakan yaitu pedoman wawancara, informed consent, dan handphone yang digunakan jntuk merekam sesi wawancara.

\section{Prosedur penelitian}

Peneliti memilih beberapa topik yang terjadi di Indonesia, setelah itu, peneliti memutuskan untuk membahas tentang kasus kegagalan program IVF di Indonesia dan bagaimana perempuan yang mengalami kasus tersebut menjalani proses kedukaannya hingga akhirnya mereka mampu menerima kegagalan program IVF-nya tersebut. Setelah itu peneliti mulai mencari jurnal yang dapat mendukung penelitian peneliti seperti buku-buku dan jurnal-jurnal tentang kedukaan serta buku-buku dan jurnal-jurnal mengenail program IVF.

Kemudian, peneliti melakukan survei untuk menentukan kriteria subyek yang sesuai dengan topik yang peneliti bahas dengan cara melakukan wawancara dengan seorang petugas data di sebuah klinik IVF di daerah Jakarta Pusat. Setelah itu, peneliti mulai mencari subyek untuk 
peneliti wawancara. Setelah peneliti mendapatkan subyek yang dibutuhkan, peneliti membuat perjanjian waktu dan tempat untuk mewawancarai subyek. Setelah itu peneliti memberikan kesempatan subyek untuk mengisi informed consent sebagai tanda kesediaan untuk menjadi subyek penelitian dalam penelitian ini dan kemudian peneliti mulai mewawancarai subyek. Setelah itu, peneliti mengolah jawaban subyek ke dalam bentuk verbatim dan koding, serta kemudian menganalisis dengan teori yang peneliti gunakan.

\section{HASIL DAN PEMBAHASAN}

Tabel 2. Gambaran Latar Belakang Subyek

\begin{tabular}{|c|c|c|c|c|}
\hline $\begin{array}{l}\text { Gambaran } \\
\text { Subyek }\end{array}$ & Subyek 1 & Subyek 2 & Subyek 3 & Subyek 4 \\
\hline Nama & ES & $\mathrm{MF}$ & $\mathrm{AL}$ & $\mathrm{RD}$ \\
\hline Tanggal Lahir & 9 Juli 1975 & 24 Agustus 1975 & 24 April 1976 & 14 Juni 1974 \\
\hline $\begin{array}{l}\text { Usia } \\
\text { tahun) }\end{array}$ & 42 & 42 & 41 & 43 \\
\hline $\begin{array}{l}\text { Usia } \\
\text { Menikah } \\
\text { tahun) }\end{array}$ & $\begin{array}{c}34 \\
\text { (tahun 2009) }\end{array}$ & $\begin{array}{c}24 \\
\text { (tahun 1999) }\end{array}$ & $\begin{array}{c}25 \\
\text { (tahun 2001) }\end{array}$ & $\begin{array}{c}40 \\
\text { (tahun 2014) }\end{array}$ \\
\hline $\begin{array}{ll}\text { Usia } & \text { Saat } \\
\text { Percobaan } & \\
\text { Pertama IVF } \\
\text { (dalam tahun) }\end{array}$ & $\begin{array}{c}40 \\
\text { (tahun 2015) }\end{array}$ & $\begin{array}{c}30 \\
\text { (tahun 2005) }\end{array}$ & $\begin{array}{c}28 \\
\text { (tahun 2004) }\end{array}$ & $\begin{array}{c}42 \\
\text { (tahun 2016) }\end{array}$ \\
\hline $\begin{array}{l}\text { Usia Perkawinan } \\
\text { Saat Percobaan } \\
\text { Pertama IVF } \\
\text { (dalam tahun) }\end{array}$ & $\begin{array}{c}6 \\
\text { (tahun 2015) }\end{array}$ & $\begin{array}{c}6 \\
\text { (tahun 2005) }\end{array}$ & $\begin{array}{c}3 \\
\text { (tahun 2004) }\end{array}$ & $\begin{array}{c}3 \\
\text { (tahun 2016) }\end{array}$ \\
\hline $\begin{array}{l}\text { Usia Perkawinan } \\
\text { Saat Percobaan } \\
\text { Kedua IVF } \\
\text { (dalam tahun) }\end{array}$ & - & $\begin{array}{c}15 \\
\text { (tahun 2014) }\end{array}$ & $\begin{array}{c}15 \\
\text { (tahun 2016) }\end{array}$ & - \\
\hline $\begin{array}{l}\text { Usia Perkawinan } \\
\text { Saat percobaan } \\
\text { Ketiga IVF } \\
\text { (dalam tahun) }\end{array}$ & - & $\begin{array}{c}16 \\
\text { (tahun 2015) }\end{array}$ & - & - \\
\hline $\begin{array}{l}\text { Usia Perkawinan } \\
\text { Saat Ini (dalam } \\
\text { tahun) }\end{array}$ & 8 & 18 & 16 & 3 \\
\hline $\begin{array}{l}\text { Jumlah } \\
\text { Percobaan IVF } \\
\text { (dalam kali) }\end{array}$ & 1 & 3 & 2 & 1 \\
\hline
\end{tabular}




\begin{tabular}{lllll}
$\begin{array}{l}\text { Memiliki anak } \\
\text { angkat }\end{array}$ & Tidak ada & Tidak ada & 2 anak & Tidak ada \\
\hline (Patricia, 2017) & &
\end{tabular}

\section{Alasan mengikuti program IVF}

Pada umumnya, alasan pasangan suami istri mengikuti program IVF adalah karena mereka ingin memiliki anak dan mereka sudah melakukan segala upaya untuk dapat hamil namun tetap tidak berhasil (Lusianti \& Wirawan, 2009). Menurut Ikawati dan Kasdu (2000), alasan pasangan suami istri mengikuti program IVF pun beragam diantaranya masalah kesuburan pada pihak suami maupun istri. Hal ini dialami oleh AL yang memiliki suami dengan kelainan azoospermia, sehingga membuat AL sulit untuk memiliki anak secara alami maupun dengan program hamil lainnya. Selain masalah kesuburan, alasan lainnya yaitu sulit untuk berhubungan dan riwayat keguguran. Hal ini dialami oleh MF yang sempat mengalami kehamilan setelah ia menikah selama 8 bulan. Akan tetapi, pada minggu kedua masa kehamilannya, MF mengalami keguguran yang disebabkan oleh adanya pengentalan darah.

Kemudian riwayat kegagalan pada program hamil lainnya dapat dijadikan suatu alasan untuk mengikuti program IVF. Hal ini dialami oleh RD yang sebelumnya pernah mengikuti program inseminasi sebanyak tiga kali dan tetap gagal. Alasan yang juga sering digunakan untuk mengikuti program IVF yaitu masalah dalam kandungan seperti kista yang berkembang serta faktor usia. Hal ini dialami oleh ES. Alasan ia mengikuti program IVF ini karena usianya yang semakin bertambah sehingga ia tidak mau mencoba cara lain lagi untuk memiliki anak.

\section{Risiko IVF}

Program IVF ini juga memiliki risiko yang dapat dialami oleh mualpasangan suami istri yang mengikuti program ini diantaranya, terjadinya stimulasi indung telur yang berlebihan dan memungkinkan untuk terjadinya penumpukan cairan dalam perut yang dapat menimbulkan efek samping seperti rasa kembung, mual-mual, muntah hingga kehilangan selera makan (Sini, 2013). Saat mengikuti program IVF, RD mengalami risiko efek stimulasi hormon yang berlebihan pada tubuhnya sehingga membuat RD menjadi mual-mual, pusing dan sangat mengganggu pekerjaannya, sehingga membuat dirinya harus istirahat di rumah untuk beberapa waktu.

Kedua, adanya kemungkinan risiko kegagalan. Semakin tinggi usia pasangan yang mengikuti program IVF, semakin meningkat juga kemungkinan kegagalan yang dialaminya. Apabila hasilnya menunjukkan tanda-tanda kegagalan, maka dokter akan meminta peserta untuk menunggu hingga mengalami menstruasi pertama setelah program. Setelah itu dokter dan peserta yang bersangkutan akan memutuskan untuk melakukan percobaan berikutnya atau tidak (Sini, 2013). MF sudah mengetahui risiko-risiko yang akan dialaminya ketika ia mengikuti program IVF, termasuk risiko yang paling besar yaitu risiko kegagalan, bahkan MF juga sudah mengalami salah satu dari risiko program IVF tersebut. Kegagalan MF pada percobaan pertama disebabkan oleh adanya cacat kromosom pada embrio yang akan ditanam pada percobaan pertama. Sedangkan kegagalan MF pada percobaan kedua disebabkan karena tidak adanya hasil penyuntikkan sel telur dan sel sperma yang berkembang menjadi embrio.

Kemudian ES juga mengalami risiko kegagalan ini yang disebabkan karena ES merasa bahwa embrio yang ada di rahim ES telah jatuh. Kemudian AL juga mengalami risiko kegagalan ini yang disebabkan karena kualitas kandungannya dianggap lemah oleh dokter. Selanjutnya RD 
pun mengalami risiko kegagalan ini yang disebabkan karena embrio yang ditanam tidak menempel dengan baik pada rahim. Terakhir yaitu risiko biaya yang dikeluarkan, kelelahan fisik dan stres secara emosional dalam menyikapi kemungkinan adanya perbedaan antara harapan dan kenyataan yang terjadi selama mengikuti program IVF (Sini, 2013).

AL juga mengalami risiko biaya yang dikarenakan kondisinya saat mengikuti program IVF percobaan keduanya. ES juga mengalami risiko biaya karena kegagalan program IVF yang dialaminya. Ia merasa bahwa tabungan yang ia miliki terbatas dan tidak dapat langsung melakukan percobaan kedua dan membuat dirinya sedih karena ia merasa orang lain dapat berhasil pada percobaan pertama, namun tidak dengan dirinya.

\section{Tahapan kedukaan}

Menurut Kübler-Ross (2009), ada lima tahap yang dimiliki oleh diri individu ketika sedang mengalami kedukaan di antaranya denial, anger, bargaining, depression, dan acceptance. Pada tahap denial, individu yang mengalami kedukaan akan bersikap menolak kenyataan yang terjadi pada dirinya. Selain itu bentuk respon denial yang dilakukan adalah selalu mencari pendapat dari berbagai pihak (Kübler-Ross, 2009). Pada kasus ES, ia sebenarnya sudah merasakan bahwa ia sudah mengalami kegagalan dalam program IVF sejak ia sudah merasakan gejala menstruasi yang biasanya ia alami tiap bulannya. Akan tetapi ES tetap berpikir positif dan yakin bahwa program IVF yang dijalaninya akan berhasil. Kemudian ES juga sempat bertanya-tanya pada dokter mengapa program IVF yang ia jalani bisa gagal dan mencari-cari kesalahan dari kegagalan program IVF yang dijalaninya, karena ia merasa bahwa dirinya sudah menjaga kondisi kandungannya dengan baik.

Selain itu, tahap ini juga dialami oleh MF dan suaminya. Ketika mereka diberitahu oleh dokter bahwa ia tidak bisa melakukan penanaman embrio ke dalam rahim MF, suaminya ingin segera bertemu untuk berbicara dengan ahli biologisnya yang saat itu melakukan proses penyuntikkan sel sperma suami MF ke dalam sel telur MF, untuk meminta penjelasan atas penyebab gagalnya proses penyuntikkan yang dilakukan oleh mereka. Kemudian, AL juga melewati tahap denial ini. Hal ini dialami oleh AL pada program IVF kedua. Dokter mengatakan bahwa embrio yang ditanamkan di rahim AL berada di kondisi lemah yang apabila dipertahankan, AL akan mengalami keguguran, sehingga AL disuruh untuk menghentikan semua obat penguat embrio. Akan tetapi AL dan suami tidak mengikuti perintah tersebut dan tetap melanjutkan pengobatan penguat embrio selama 5 minggu kehamilan.

Tahap denial juga dialami oleh RD. Hal ini terbukti, ketika RD tidak mendapat hasil embrio yang sesuai dengan yang diharapkan, padahal RD merasa bahwa ia sudah melakukan saran dan anjuran dokter. Selain itu juga, RD sempat mencari second opinion dengan dokter akupuntur di rumah sakit lain dan mau mengganti dokter untuk percobaan program IVF keduanya karena merasa tidak puas dengan pelayanan dan jawaban yang diberikan oleh dokter pertama yang melakukan percobaan program IVF dengan RD.

Pada tahap anger, individu tidak dapat menahan rasa denial yang ia miliki tersebut dan berkembang menjadi rasa amarah, gusar, iri hati dan kebencian. Tahap anger ini sangat sulit diatasi oleh keluarga atau orang-orang terdekat. Hal ini dikarenakan oleh fakta bahwa rasa amarah yang dialami oleh individu diekspresikan dengan berbagai cara ke lingkungannya pada saat-saat yang tidak menentu (Kübler-Ross, 2009). ES juga melewati tahapan anger ini. ES juga merasa sedih dan kesal atas kegagalan dari proses IVF yang dijalaninya serta 
bertanya-tanya pada diri sendiri dan berkaca pada diri sendiri atas kegagalan proses IVF yang telah dialaminya. Selain itu, ES juga merasa kesal, karena ES tidak mampu menahan rasa ingin buang air kecil sehingga ia turun dari tempat tidur menuju kamar mandi.

AL juga sempat melewati tahap anger ini. AL marah dengan dirinya sendiri setelah kegagalan pertamanya. AL merasa bahwa kegagalan pertamanya merupakan sepenuhnya kesalahannya, terutama setiap ia melihat suaminya, ia makin menyalahkan dirinya sendiri. Selain itu AL sempat merasa sangat kecewa dengan Tuhan hingga ia meninggalkan ibadahnya selama sebulan ketika ia mengalami kegagalan pertamanya. Tahap anger ini juga dialami oleh RD. Hal ini terbukti dari rasa kesal dan marah karena dokter tidak dapat menjelaskan apa penyebab sesungguhnya dari kegagalan program IVF yang dijalani oleh RD. Selain itu, ia juga merasa kesal tidak dapat menemukan penyebab kegagalan program IVF-nya melalui browsing di internet.

Pada tahap bargaining, individu tidak mampu lagi untuk menghadapi kenyataan yang menyedihkan untuk individu yang bersangkutan pada tahap-tahap awal dan pada tahap ini juga rasa marah yang muncul diarahkan ke Tuhan (Kübler-Ross, 2009). Pada kasus ES ketika ia diberitahu bahwa program yang ia jalani tidak berhasil, beliau merasa bahwa Tuhan tidak adil pada ES. ES merasa heran melihat orang-orang yang tidak memperhatikan kesehatannya, namun berhasil memiliki anak dengan mudahnya, sedangkan dirinya yang mampu menjaga kesehatannya dengan baik, namun sulit untuk memiliki keturunan. Selain ES, AL juga mengalami tahap bargaining. AL sempat bertanya-tanya pada Tuhan. Ia merasa Tuhan tidak adil dengannya. Tahap bargaining ini juga sempat dialami oleh RD. Hal ini terbukti ketika ia merasa sudah berusaha semaksimal mungkin dan melakukan segala cara untuk memiliki keturunan, mulai dari hidup sehat, tidak merokok dan menjaga kesehatannya namun ia tidak mendapatnya, sedangkan banyak orang yang bersantai-santai dan bahkan tidak mengharapkan anak namun tetap diberikan oleh Tuhan.

Pada tahap depression, individu sudah tidak dapat menyangkal hal yang menyebabkan respon grief pada dirinya muncul. Hal ini dikarenakan semakin jelasnya hal-hal yang membuktikan bahwa individu tersebut memiliki sesuatu yang membuat ia menjadi merasa sedih (respon grief). Semakin jelasnya kenyataan tersebut merubah sikap individu yang bersangkutan mulai dari sikap denial dan anger yang dialami menjadi sebuah rasa kehilangan yang sangat mempengaruhi hidupnya (Kübler-Ross, 2009). Berdasarkan pengalaman yang ES alami, ia masih sering menangis ketika mengingat kegagalannya dan ketika ia menangis, ia juga merasa dirinya kesepian dan merasa tidak ada yang mau menemaninya sehingga ia sering menangis sendiri dan kerap kali mengalami sakit migrain. MF juga sempat melewati tahap depression ini. Hal ini dirasakan oleh MF terutama ketika ia mengalami kegagalan program IVF keduanya yang ia lakukan di Indonesia. Hal ini dikarenakan MF sudah mendapat embrio yang hidup, namun mengalami kerusakan pada kromosom sehingga dokter tidak jadi menanam embrio tersebut ke rahim MF.

Kemudian, AL juga sempat melewati tahap depression ini. Saat pertama kali mengetahui kegagalan program IVF-nya, ia merasa sedih dan merasa bahwa ia tidak bisa melakukan percobaan selanjutnya karena masalah biaya. Selain itu, AL juga merasa down ketika ia mendapat hasil positif hamil dengan kondisi embrio yang mengawatirkan. Ia merasa bahwa embrio tersebut akan gugur dengan kondisi yang mengawatirkan seperti yang dinyatakan oleh dokter. Kemudian AL juga sempat merasa sering merasa sedih tiap kali ia melihat suaminya sedih dan merasa sangat bersalah terhadap suaminya terutama setelah kegagalan program IVF 
pertamanya. Tahap depression ini juga sempat dialami oleh RD. Hal ini terbukti ketika RD mengetahui bahwa dari 11 telur yang diambil hanya 3 embrio yang berkembang dengan kualitas yang kurang pula. RD merasa sangat down dan pesimis karena ia tidak memiliki cadangan embrio yang berkualitas cukup. Hal ini membuat RD tidak ingin melanjutkan proses IVF lagi meskipun sudah diberi semangat oleh suami dan dokter yang menanganinya karena menurut RD percuma.

Pada tahap acceptance, individu tidak berarti mulai memasuki tahap bahagia karena individu yang bersangkutan telah menerima apa yang terjadi dalam hidupnya. Setelah individu tersebut mengalami keempat tahap grief yang telah dijelaskan di atas, ia akan bersikap pasrah (KüblerRoss, 2009). ES sudah mulai mencoba untuk mencapai tahap ini, karena ibu ES juga masih harus memikirkan usianya. MF juga sudah mencapai tahap akhir dari proses grief ini. Hal ini terlihat dari sikap MF yang sudah dapat menceritakan pengalamannya tanpa perasaan negatif. Selain itu MF juga sudah mampu menerima kondisinya dan suami yang tidak mampu menghasilkan keturunan lagi seperti dulu, mulai dari kondisi sel telur MF yang sudah memburuk hingga kualitas sel sperma suaminya yang sudah mulai menurun. Kemudian, AL juga sudah menjalani tahap acceptance ini. AL sudah mampu menerima kegagalan program IVF yang dijalaninya karena menurutnya hidup harus tetap berjalan. Meskipun terkadang ia masih merasa kecewa karena merasa sudah berusaha semaksimal mungkin namun hasilnya tidak sesuai dengan yang diinginkan. Saat ini, RD juga sudah dapat menerima kegagalan program IVF yang ia jalani sebelumnya. Oleh karena itu, ia siap untuk mencobanya kembali.

\section{Faktor yang mempengaruhi kedukaan}

Menurut Aiken (dikutip dalam Cahyasari \& Sedjo, 2008), terdapat tiga kedukaan individu di antaranya, hubungan individu dengan orang yang mengalami kematian tersebut. Mereka saling memiliki hubungan yang sangat baik dengan jangka waktu yang cukup panjang, sehingga semakin dekat dan lama hubungan yang mereka jalin, semakin sulit pula individu yang ditinggalkan, melewati proses kedukaannya. Begitu juga sebaliknya, apabila mereka tidak memiliki hubungan yang sangat dekat dengan jangka waktu yang tidak lama, semakin mudah pula individu yang ditinggalkan, melewati proses kedukaannya. Hal ini dialami oleh ES. Ia hanya mampu merasakan hubungan dengan calon bayinya hanya dalam kurun waktu delapan belas hari sebelum ia mengalami keguguran. Ketika ES masih memiliki embrio di rahimnya, ia sudah merasa bahwa embrio yang ada di rahimnya tersebut sedang berkembang dan ia merasa bertanggung jawab dengan embrio yang ada di rahimnya tersebut. AL juga mampu merasakan hubungan dengan calon bayinya dalam kurun waktu enam minggu sebelum ia mengalami keguguran pada percobaan IVF pertama. Kemudian pada percobaan IVF kedua, AL mampu merasakan hubungan dengan calon bayinya dalam kurun waktu lima minggu sebelum ia kembali mengalami keguguran. Ketika AL masih memiliki embrio di dalam rahimnya, ia melakukan hal-hal yang umumnya dilakukan oleh perempuan hamil seperti mengajak berbicara sehingga hubungan AL semakin dekat dengan embrionya tersebut.

Akan tetapi hal berbeda dialami oleh RD. Embrio di rahim RD bertahan selama kurang lebih dua minggu, namun RD tidak merasakan hubungan apapun karena selama dua minggu kehamilannya tersebut ia lebih merasa berhati-hati daripada menjalin hubungan dengan embrionya tersebut. MF juga tidak merasakan hubungan apapun dengan calon bayinya karena ia mengalami kegagalan program IVF sebelum melakukan proses penanaman embrio pada percobaan IVF pertamanya yang dikarenakan adanya cacat kromosom pada embrio yang akan ditanam. Kedua, kepribadian, usia, jenis kelamin dari individu yang ditinggalkan. Individu dengan usia yang lebih muda, cenderung untuk lebih mudah mengalami stres akibat kedukaan 
yang dialaminya. Ketiga, proses kematian yang dialami oleh orang yang mengalami kematian tersebut. Hal ini dapat menimbulkan berbagai macam reaksi terhadap individu yang ditinggalkan (Cahyasari \& Sedjo, 2008). Faktor ini dimiliki oleh ES karena embrio di dalam rahimnya tidak berkembang, sehingga akhirnya ia mengalami kegagalan. Selain ES, AL juga mengalami faktor ini pada percobaan pertama karena kelalaian AL dalam menjaga kandungannya. Kemudian pada percobaan kedua, AL juga memiliki faktor ini. Hal ini dikarenakan kualitas kandungannya dianggap lemah oleh dokter. Faktor ini juga dimiliki oleh RD karena embrio yang ditanam tidak menempel dengan baik pada rahim.

Keempat yaitu dukungan sosial. Kurangnya dukungan dari orang-orang terdekat di sekitar individu yang bersangkutan akan membuat individu tersebut merasa tidak dapat berdaya dan cukup kuat untuk melewati proses kedukaannya (Cahyasari \& Sedjo, 2008). Faktor ini dimiliki oleh ES untuk membantu ES menjalani proses kedukaannya. ES mengaku mendapat dukungan dari suaminya dalam menjalani proses kedukaan ini. Selain ES, MF juga mendapat dukungan sosial dari keluarganya sehingga ia mampu segera menerima kegagalan program IVF yang ia jalani. Kemudian AL juga memiliki faktor ini. AL mendapat dukungan dari teman-temannya dari berbagai sumber. Selain dari teman-temannya, AL juga mendapat dukungan dari salah satu anak angkatnya. Faktor ini juga dimiliki oleh RD. Ia merasa mendapat dukungan dari suami dan keponakannya.

\section{KESIMPULAN DAN SARAN}

Berdasarkan hasil penelitian dapat disimpulkan bahwa dari empat subyek, tiga subyek sudah melewati semua tahapan kedukaan dengan cara mereka masing-masing. Dari tahap denial, semua subyek melewati tahap ini. Dari tahap anger, tiga dari empat subyek meleqati tahap ini. Dari tahap bargaining, tiga dari empat subyek melewati tahap ini. Dari tahap depression, semua subyek melewati tahap ini. Dari tahap acceptance, semua subyek melewati tahap ini.

Kemudian dari segi faktor yang mempengaruhi kedukaan, dua dari empat subyek memiliki faktor hubungan dengan calon bayi. Kemudian tiga dari empat subyek memiliki proses kematian pada calon bayi mereka. Selanjutnya, semua subyek memiliki faktor dukungan sosial. Selain itu berdasarkan hasil penelitian, faktor kepribadian, usia dan jenis kelamin tidak mempengaruhi kedukaan pada perempuan yang mengalami kegagalan program IVF. Saran yang berkaitan dengan manfaat teoretis dari penelitian ini yaitu, peneliti dapat lebih fokus pada dukungan sosial yang diterima oleh perempuan yang pernah mengalami kegagalan program IVF serta gambaran kedukaan suami ketika istrinya mengalami kegagalan pada program IVF. Selain itu pada penelitian selanjutnya diharapkan untuk memperhatikan jumlah subyek untuk mengantisipasi hal yang tidak diinginkan misalnya subyek tidak bersedia untuk diwawancara atau subyek tidak sesuai dengan kriteria yang telah ditetapkan sebelumnya.

Saran yang berkaitan dengan manfaat praktis dari penelitian ini yaitu, penelitian ini dapat digunakan oleh para perempuan yang berencana untuk mengikuti program IVF. Penelitian ini akan memberi gambaran kemungkinan-kemungkinan apa saja yang akan terjadi ketika memutuskan untuk mengikuti program IVF dan membantu para perempuan yang berencana untuk mengikuti program IVF untuk mempersiapkan kemungkinan terburuk dari program ini, yaitu kegagalan. Hal ini berguna supaya ketika mereka mengalami kegagalan pada program IVF-nya dan mereka merasa berduka karenanya merupakan hal yang mungkin saja dapat dialami, namun mereka harus mampu menerimanya dan melanjutkan hidup. Selain itu peran 
dukungan sosial dari orang-orang terdekat juga sangat penting untuk mereka yang sedang menjalani proses kedukaan.

\section{Ucapan Terima Kasih}

Terima kasih peneliti ucapkan kepada Klinik Morula IVF Jakarta yang sudah membantu dalam proses penelitian ini. Selain itu, peneliti juga mengucapkan terima kasih kepada para subyek yang sudah mau membantu dalam proses penelitian ini melalui pengalaman mereka selama mengikuti program IVF.

\section{REFERENSI}

Adilia, M. H. (2010). Hubungan self esteem dengan optimisme meraih kesuksesan karir pada mahasiswa fakultas psikologi uin syarif hidayatullah Jakarta. Diunduh dari repository.uinjkt.ac.id/dspace/bitstream/123456789/3435/1/MUHARNIA\%20DEWI \%20ADILA-FPS.pdf

Cahyasari, I. \& Sedjo, P. (2008). Grief pada remaja putra karena kedua orangtuanya meninggal.

Diunduh

dari www.gunadarma.ac.id/library/articles/graduate/psychology/2009/Artikel_10503095. pdf

Crawford, M. \& Unger, R. (2000). Women and gender: A feminist psychology (ed. 3). NY: Mc-Graw Hill.

Ikawati, Y. \& Kasdu, D. (2000). Bayi tabung sebuah harapan baru. Jakarta: Mapiptek

Kübler-Ross, E. (2009). On death and dying:what the dying have to teach doctors, nurses, clergy and their own families. London: Routledge.

Lusianti, M. \& Wirawan, H. E. (2009). Gambaran kecemasan wanita dewasa muda yang mengikuti program bayi tabung. Arkhe Jurnal Ilmiah Psikologi, 14, 145-158.

Rahmanawati, A. (2014). Studi mengenai gambaran hardiness pada mahasiswa yang sedang mengerjakan skripsi di fakultas psikologi universitas padjajaran. Diunduh dari repository.unpad.ac.id/19892/1/Studi-Mengenai-Gambaran-Hardiness.pdf

Sini, I. R. (2013). Bayi tabung mempersiapkan kehamilan dan menanti kehamilan. Jakarta: Gramedia Pustaka Utama

Stroebe, W. \& Stroebe, M. S. (1987). Bereavement and health: The psychological and physical consequences of partner loss. NY: Cambridge University Press. 